\title{
Technological solutions for screening and geolocation of COVID-19 infected people: A country comparison approach
}

\author{
Fernando Almeida ${ }^{*}$ (iD) \\ ${ }^{1}$ Faculty of Engineering, University of Porto, Industrial and Systems Engineering Sector, INESC TEC, Portugal
}

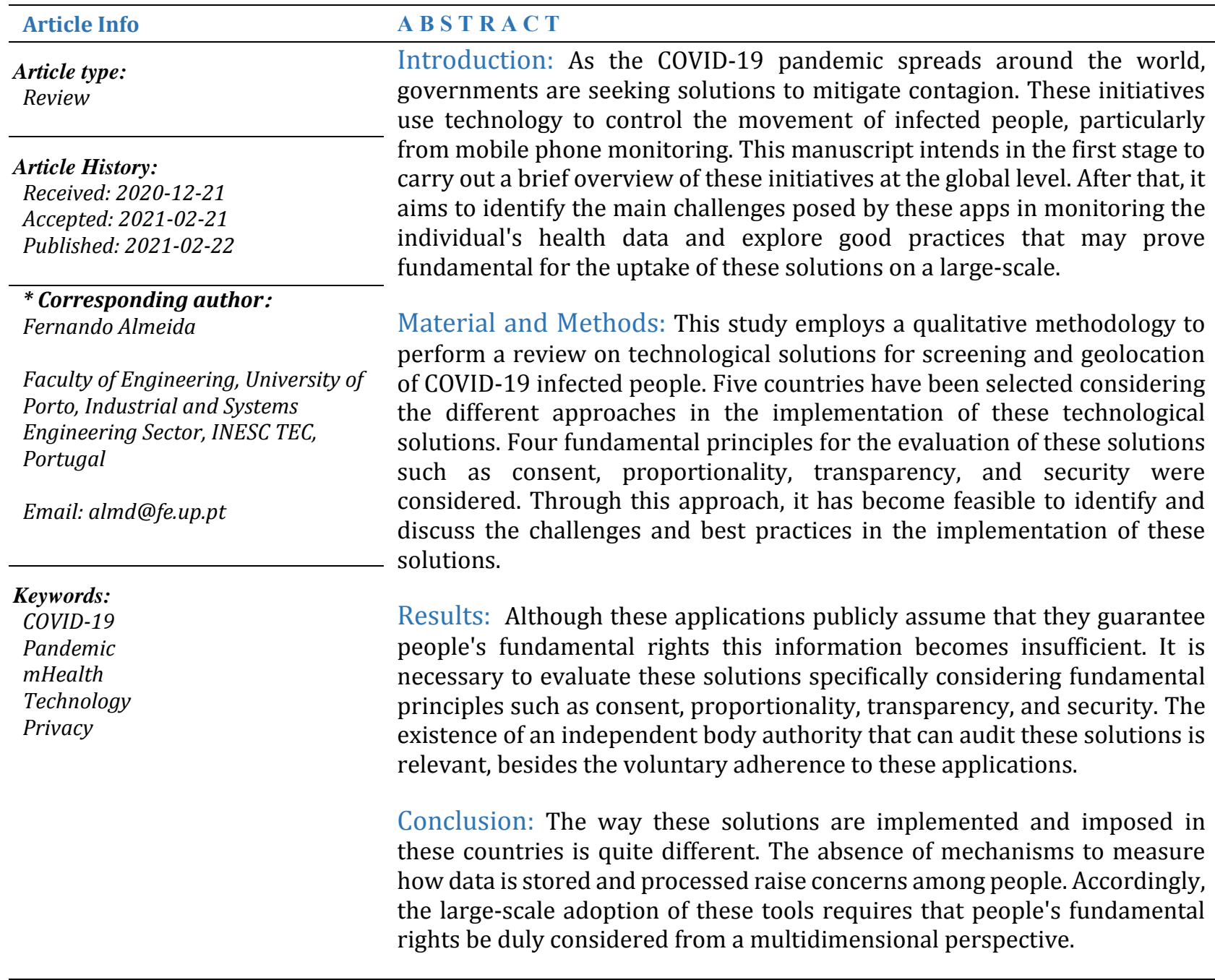

Cite this paper as:

Almeida F. Technological Solutions for Screening and Geolocation of COVID-19 Infected People: A Country Comparison Approach. Front Health Inform. 2021; 10: 62. DOI: 10.30699/fhi.v10i1.270

\section{INTRODUCTION}

The health sciences sector is one of the main focuses of technological evolution to offer technological solutions to increase the quality of life of citizens and bring health services closer to the population. Science and technology have been important elements in promoting the health and treatment of diseases. In recent years, the area of mobile health research (mHealth) has been constantly expanding. The mHealth concept encompasses the use of mobile computing and communications technologies in health care and public health $[\underline{1}, \underline{2}]$. Mobile health applications serve a heterogeneous audience (e.g., physicians, nurses, patients, family members) and a wide variety of purposes that include the most diverse areas of health and disease management []․ It is estimated that information and communication technologies and telemedicine can contribute to improving the efficiency of health services and improve citizens' quality of life, leading to more sustainable health systems []].

The greatest advantages of using mobile devices for health are associated with the characteristics of these resources. They are personal, portable, have sensors, and are connected to the Internet []․ Furthermore, Sannino et al. [] ] state that they are intelligent 
because they have processing capacity. In this way, they can be adaptable and change their behavior according to the usage pattern of users. They can serve users both in daily life and during hospitalization or rehabilitation.

mHealth has gained prominence in the field of health care interoperability. It is seen as a factor that can blur the distinction between traditional health care provision and self-administration [7]. Furthermore, it has contributed to ensuring that health records are not dispersed and can be accessed by the user []. However, mHealth poses challenges in the legal framework, particularly regarding the privacy of personal data, its access by the service provider and/or other users, and its sharing with other applications [ㅁ-11].

The current context motivated by the COVID-19 pandemic suggests that the use of mobile technology can support diagnosis and reduce the rate of contagion of the disease. Several mHealth initiatives have emerged in the local context promoted by the national government. In countries like China and South Korea, this approach has promoted the reduction and control of the risks of contagion $[\underline{12}$, 13]. However, in several countries, especially in Europe, these solutions are viewed with some mistrust by governments and populations and often seen as contrary to the principles of freedom of the populations because they can expose citizens' personal data. In this sense, this short communication aims to provide an overview of several technological solutions that have promoted the control of COVID-19 and, after that, it intends to identify a set of challenges and good practices that enable its large-scale adoption.

\section{MATERIAL AND METHODS}

Governments worldwide have promoted mHealth applications for screening and geolocation of COVID19 infected people to mitigate their spread. These applications stand out for controlling the movement of infected people by monitoring their location based on mobile phone information. It was from Asian countries that the first examples of these applications arrived, but they have meanwhile spread and been adopted by other governments. An attempt was made to summarize these initiatives given their specifications and geographical coverage, including examples from Asia and Europe. In this sense, a qualitative approach was followed in which five case studies with different approaches are identified in the implementation of technological solutions for diagnosis and control of those infected with COVID19. In the first stage, a summary description of the solutions adopted in each country is made. Afterward, a set of principles and specific criteria are identified to evaluate these solutions. Finally, a comparative evaluation of these solutions is performed.

\section{China}

In China, where the outbreak of COVID-19 was initiated, there was a tight control with the citizens to prevent the spread of the infection. Each person has a QR code that is read through the cell phone's camera. The system assigns colors to citizens according to their travel patterns in recent weeks and their state of health. Three colors are assigned: (i) green indicates that the citizen does not need to isolate himself/herself; (ii) yellow indicates that the citizen needs to isolate himself/herself for one week; and (iii) red indicates that the citizen must isolate himself/herself for two weeks. According to the color code, entry into certain public places is forbidden to those who are yellow and red [14]. Moreover, other non-integrated technological solutions have been adopted to avoid contagion, such as artificial intelligence helmets to measure temperature and recognition drones to alert people for not wearing masks in public [15].

\section{South Korea}

South Korea was also among the first countries to adopt mHealth solutions to control the spread of the virus. A government app is adopted that lets every citizen know if they have been close to a confirmed case of COVID-19. If so, the user receives a notification and he/she will have to contact the health authorities to perform a test of COVID-19 and should be in quarantine for 15 days. Quarantine compliance is mandatory and verified by the geolocation of each person [16].

\section{Singapore}

Singapore government advises citizens to adopt TraceTogether. Unlike the two previous examples, adherence to the application is voluntary. This was the first government app to use Bluetooth technology to track contacts of infected people. Therefore, the application does not collect data about the individual's GPS location. It anonymizes and encrypts the data and keeps these records for 25 days. Only three items are recorded in the app: (i) the mobile number, identification details, and random anonymized user [17].

\section{Poland}

Poland was the first country in Europe to use a mobile phone application that enables police authorities to monitor the location of citizens. The application developed by TakeTask applies exclusively to persons diagnosed with COVID-19 or who have been in contact with infected persons. It is used by the police to detect possible breaches of quarantine. Police authorities contact all individuals registered with the application daily to request their 
geolocation. Besides the location data, the user is asked to take a selfie, and each person has 20 minutes to check it [18]. At this stage, Poland does not yet have a contact tracing application, but efforts are being made to implement it in the short term. Additionally, it has already been established that membership is voluntary.

\section{Germany}

The Coronavirus-Datenspende app was developed by Tryveand Robert Koch-Institutwith the support of government authorities. The objective of this application is to restrict the spread rate of COVID-19. This requires a smartphone and a fitness bracelet or smartwatch to recognize the symptoms of a virus infection. This information is useful to detect the virus at an early stage and prevent its geographical spread. This approach offers greater reliability in virus infection indicators, as sensor data are more reliable than manually entering disease symptoms into the smartphone [19].

\section{RESULTS}

The large-scale adoption of technology for screening and geolocation of COVID-19 infected people assumes that these applications consider people's fundamental rights. It is necessary to evaluate these technological solutions according to fundamental principles such as consent, proportionality, transparency, and security. Table 1 summarizes the criteria that should be implemented by applications and raises some questions that should be considered.

Furthermore, it is also essential that adherence to these applications is voluntary. Each government, together with the health authorities, must inform the population about the advantages of adopting these platforms. Equally important is to ensure that there is an independent agency that can audit the registration and processing of personal data, as advocated by Kotz et al. [20] as a way to increase the safety of mHealth technology and ensure the protection of personal health information.

Finally, the implemented solutions in each country are evaluated and compared (Table 2) according to previously established criteria.

The following scale was adopted; Y: implemented; N: not implemented; P: partially implemented; and n/a: information not available. The different approaches followed in the implementation of the solutions in each country lead to different levels of performance for each criterion. Explicit consent is only possible in voluntary adoption solutions. Only the technological solution implemented in Germany uses open-source technologies and open standards. Only in this solution, the security of data transmission can be audited.
Table 1: Benchmark for mHealth solutions evaluation in the fight against COVID-19

\begin{tabular}{|c|c|c|}
\hline Principle & Criteria & Questions \\
\hline \multirow{3}{*}{ Consent } & $\begin{array}{l}\text { Explicit Consent } \\
\text { (EC) }\end{array}$ & $\begin{array}{l}\text { Is there explicit } \\
\text { consent to the } \\
\text { processing of } \\
\text { personal data? }\end{array}$ \\
\hline & $\begin{array}{l}\text { Sensitive Data } \\
\text { (SD) }\end{array}$ & $\begin{array}{l}\text { Is there specific } \\
\text { permission, where } \\
\text { necessary, for the } \\
\text { processing of } \\
\text { sensitive personal } \\
\text { data? }\end{array}$ \\
\hline & $\begin{array}{l}\text { Identifiable } \\
\text { Permission (IP) }\end{array}$ & $\begin{array}{l}\text { Is the relationship } \\
\text { between the } \\
\text { functionality of the } \\
\text { application and the } \\
\text { requested } \\
\text { permission } \\
\text { explained? }\end{array}$ \\
\hline \multirow{3}{*}{ Proportionality } & $\begin{array}{l}\text { Personal Data } \\
\text { Need (PDN) }\end{array}$ & $\begin{array}{l}\text { Are appropriate } \\
\text { and necessary } \\
\text { permissions } \\
\text { requested for the } \\
\text { execution of the } \\
\text { application } \\
\text { functionalities? }\end{array}$ \\
\hline & $\begin{array}{l}\text { Data minimization } \\
(\mathrm{DM})\end{array}$ & $\begin{array}{l}\text { Is the minimum } \\
\text { amount of personal } \\
\text { information } \\
\text { required for the } \\
\text { operation of the } \\
\text { application? }\end{array}$ \\
\hline & Data Expiry (DE) & $\begin{array}{l}\text { Is an expiry date set } \\
\text { for personal data } \\
\text { under the } \\
\text { temporary } \\
\text { measures to } \\
\text { combat COVID-19? }\end{array}$ \\
\hline \multirow{3}{*}{ Transparency } & Policy Inquiry (PI) & $\begin{array}{l}\text { Is there a privacy } \\
\text { policy that can be } \\
\text { consulted by the } \\
\text { user? }\end{array}$ \\
\hline & $\begin{array}{l}\text { Access to Personal } \\
\text { Data (APD) }\end{array}$ & $\begin{array}{l}\text { Do users have } \\
\text { access to their } \\
\text { personal data? }\end{array}$ \\
\hline & $\begin{array}{l}\text { Access to Third } \\
\text { Parties (ATP) }\end{array}$ & $\begin{array}{l}\text { Are users informed } \\
\text { about the potential } \\
\text { sharing of data with } \\
\text { third parties? }\end{array}$ \\
\hline \multirow{3}{*}{ Security } & $\begin{array}{l}\text { Security Measures } \\
\text { Information (SMI) }\end{array}$ & $\begin{array}{l}\text { Are users informed } \\
\text { about the security } \\
\text { measures } \\
\text { implemented by } \\
\text { the application? }\end{array}$ \\
\hline & $\begin{array}{l}\text { Data Transfer } \\
\text { Security (DTS) }\end{array}$ & $\begin{array}{l}\text { Is the data transfer } \\
\text { in the application } \\
\text { performed } \\
\text { securely? }\end{array}$ \\
\hline & $\begin{array}{l}\text { Open Source and } \\
\text { Open Data (OSOD) }\end{array}$ & $\begin{array}{l}\text { Is the application } \\
\text { code open and are } \\
\text { open standards } \\
\text { used? }\end{array}$ \\
\hline
\end{tabular}


Table 2: Comparative evaluation of solutions implemented in each country

\begin{tabular}{|c|c|c|c|c|c|}
\hline & 己. & 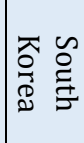 & 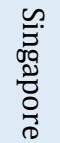 & $\begin{array}{l}\overline{0} \\
\stackrel{0}{0} \\
\tilde{0}\end{array}$ & 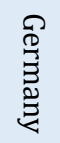 \\
\hline EC & $\mathrm{N}$ & $\mathrm{N}$ & $\mathrm{Y}$ & $\mathrm{Y}$ & $\mathrm{Y}$ \\
\hline SD & $\mathrm{N}$ & $\mathrm{N}$ & $\mathrm{n} / \mathrm{a}$ & $\mathrm{N}$ & $\mathrm{P}$ \\
\hline IP & $\mathrm{P}$ & $\mathrm{P}$ & $\mathrm{Y}$ & $P$ & $\mathrm{P}$ \\
\hline PDN & $\mathrm{n} / \mathrm{a}$ & $\mathrm{n} / \mathrm{a}$ & $\mathrm{Y}$ & $\mathrm{n} / \mathrm{a}$ & $\mathrm{Y}$ \\
\hline DM & $\mathrm{n} / \mathrm{a}$ & $\mathrm{n} / \mathrm{a}$ & $\mathrm{Y}$ & $\mathrm{N}$ & $\mathrm{Y}$ \\
\hline $\mathrm{DE}$ & $\mathrm{N}$ & $\mathrm{N}$ & $\mathrm{Y}$ & $\mathrm{n} / \mathrm{a}$ & $\mathrm{Y}$ \\
\hline PI & $Y$ & $Y$ & $\mathrm{Y}$ & Y & $\mathrm{Y}$ \\
\hline APD & $P$ & $\mathrm{Y}$ & $\mathrm{Y}$ & $\mathrm{N}$ & $\mathrm{P}$ \\
\hline ATP & $\mathrm{N}$ & $\mathrm{Y}$ & $\mathrm{Y}$ & $\mathrm{n} / \mathrm{a}$ & $\mathrm{n} / \mathrm{a}$ \\
\hline SMI & $\mathrm{n} / \mathrm{a}$ & $Y$ & $\mathrm{Y}$ & $\mathrm{n} / \mathrm{a}$ & $\mathrm{Y}$ \\
\hline DTS & $\mathrm{n} / \mathrm{a}$ & $\mathrm{n} / \mathrm{a}$ & $\mathrm{n} / \mathrm{a}$ & $\mathrm{n} / \mathrm{a}$ & $\mathrm{Y}$ \\
\hline OSOD & $\mathrm{N}$ & $\mathrm{N}$ & $\mathrm{N}$ & $\mathrm{N}$ & $\mathrm{Y}$ \\
\hline
\end{tabular}

\section{DISCUSSION}

Human Rights Watch (HRW) has considered that tracking and geolocation applications used in several countries to fight the propagation of COVID-19 pose serious risks to human rights by compromising the right to privacy and other fundamental rights [21]. In the study conducted by Van Kolfschooten and Ruijter it is confirmed this view by indicating that these applications can serve as grounds for unnecessary and disproportionate citizen surveillance and control measures [22]. In this sense, public health policies should guarantee citizens' rights and freedoms.

Governments claim that these measures are temporary until the pandemic is under control and a vaccine is available. However, these justifications are viewed with some suspicion by citizens. As HRW argues, these measures in some countries could be made permanent in an expanded surveillance regime [21]. Apart from the right to privacy, other rights may be compromised, such as the right to movement, expression, and association [2]ㅡ. These freedoms may be at risk if these applications are used to identify undesirable behavior, to signal unadvisable routes or destinations, or to detract in advance from groupings of personnel. In this sense, increased state digital surveillance powers threaten the rights and freedoms and citizens that may degrade confidence in public authorities.

Another risk factor pointed out by HRW is the scope of these programs that may not protect the entire population [21]. Several groups may be marginalized, such as migrant workers, refugees, and the homeless. These groups typically do not have access to the Internet and mobile technology and would, therefore, be inhibited from using these applications. This would put their health and livelihoods at risk. In the same vein, the UN [24] refers to the heterogeneity of the impact of COVID-19 on the population. Its impact is greatest in countries with low levels of economic development and the most disadvantaged classes. The digitalization of the economy has been accelerated by COVID-19 which has resulted in people being heavily dependent on technologies to access health services and work [25]. Access to technology is unequivocally uneven for the entire population, with people on lower incomes being those most exposed to the transmission of the virus [26].

The role that technology can play in combating the spread of COVID-19 and its effects does not seem to be under discussion. Indeed, technology can be a relevant element in achieving social goals and ensuring health protection. As it is indicated by Elavarasanand Pugazhendhi, the functions of selfdiagnosis and symptom control can be important in mitigating the spread of the disease and supporting the mental stabilization of users [27]. However, what is under discussion are the conditions of security in the production, access and use of the information processed, stored, and transmitted by the adoption of these platforms.

\section{CONCLUSION}

Several mHealth applications have emerged internationally in response to the challenges of controlling the OVID-19 pandemic. These applications have the fundamental objective of mitigating the spread of the pandemic among the population. For this purpose, we can essentially find mobile applications that aim to identify sources of contagion through the geolocation of devices and Bluetooth, and applications that aim to control compliance with quarantine measures imposed by governments. In some countries (e.g. China, South Korea, Poland) these applications are mandatory for use by the population, while in other countries (e.g. Singapore, Germany) adherence to these solutions is voluntary.

These applications have raised a great debate in the community about the risks posed to human rights, such as the right to privacy, movement, expression, and association. The mandatory adherence to these applications and the absence of mechanisms to measure how data is stored and processed feed these concerns. This form of access and control of personal data can undermine confidence in public authorities and democratic systems. In this sense, it is argued that the large-scale adoption of these tools requires that people's fundamental rights be duly considered from a multidimensional perspective, considering consent, proportionality, transparency, and security. Furthermore, it is essential that adherence to these platforms is voluntary and that an independent body responsible for auditing the personal data stored and processed by the applications is established. 
This study contains some limitations that need to be registered. COVID-19 pandemic is an unpredictable and fast evolving event, and the authors only had available data in a limited set of countries at the time of preparing the manuscript. The authors only discussed the relevance of technology for screening and geolocation of COVID-19 infected people and to mitigate their spread. However, technologies can and have been used for other health services during the pandemic, including conducting telehealth consultation sessions, distribute key disease control guidelines, symptom assessment and tracking, social media support group, etc. Another relevant issue is that the discussion of health data privacy greatly depends on the purpose of data use and the likelihood of privacy invasion as related to the adoption of specific data collection/storage/linkage protocols. Without knowing how contact tracing data is collected and used, it would be difficult to assess the risk to data privacy.

\section{AUTHOR'S CONTRIBUTION}

The author agree on this final form of the manuscript, and attested that all authors contributed in the final draft of the manuscript.

\section{CONFLICTS OF INTEREST}

The author declare no conflicts of interest regarding the publication of this study.

\section{FINANCIAL DISCLOSURE}

No financial interests related to the material of this manuscript have been declared.

\section{REFERENCES}

1. Davis TL, DiClemente R, Prietula M. Taking mHealth forward: Examining the core characteristics. JMIR Mhealth Uhealth. 2016; 4(3): e97. PMID: 27511612 DOI: $10.2196 / \mathrm{mhealth} .5659$ [PubMed]

2. Park YT. Emerging New Era of Mobile Health Technologies. Healthc Inform Res. 2016; 22(4): 2534. PMID: 27895955 DOI: 10.4258/hir.2016.22.4.253 [PubMed]

3. Riley WT, Rivera DE, Atienza AA, Nilsen W, Allison SM, Mermelstein R. Health behavior models in the age of mobile interventions: Are our theories up to the task? Transl Behav Med. 2011; 1(1): 53-71. PMID: $21796270 \quad$ DOI: $\quad 10.1007 / \mathrm{s} 13142-011-0021-7$ [PubMed]

4. Rowland SP, Fitzgerald JE, Holme T, Powell J, McGregor A. What is the clinical value of mHealth for patients? NPJ Digit Med. 2020; 3: 4. PMID: 31970289 DOI: $10.1038 / \mathrm{s} 41746-019-0206-x$ [PubMed]

5. Whittaker R. Issues in mHealth: Findings from key informant interviews. J Med Internet Res. 2012; 14(5): e129. PMID: 23032424 DOI: 10.2196/jmir.1989 [ubMed]

6. Sannino G, Bouguila N, De Pietro G, Celesti A. Artificial intelligence for mobile health data analysis and processing. Mobile Information Systems. 2019; 2019: 673463.

7. Lehne M, Sass J, Essenwanger A, Schepers J, Thun S. Why digital medicine depends on interoperability. NPJ Digit Med. 2019; 2(79): 1-5. PMID: 31453374 DOI: 10.1038/s41746-019-0158-1 [PubMed]

8. Vaghefi I, Tulu B. The continued use of mobile health apps: Insights from a longitudinal study. JMIR Mhealth Uhealth. 2019; 7(8): e12983. PMID: 31469081 DOI: 10.2196/12983 [ubMed]

9. Abeler J, Bäcker M, Buermeyer U, Zillessen H. COVID19 contact tracing and data protection can go together. JMIR Mhealth Uhealth. 2020; 8(4): e19359.
PMID: 32294052 DOI: 10.2196/19359 [PubMed]

10. Akbar S, Coiera E, Magrabi F. Safety concerns with consumer-facing mobile health applications and their consequences: A scoping review. J Am Med Inform Assoc. 2020; 27(2): 330-40. PMID: 31599936 DOI: 10.1093/jamia/ocz175 [PubMed]

11. Rahman F, Addo ID, Ahamed SI, Yang JJ, Wang Q. Chapter two: Privacy challenges and goals in mHealth systems. Advances in Computers. 2016;102: 47-62.

12. Holmes A. South Korea is relying on technology to contain COVID-19, including measures that would break privacy laws in the US - and so far, it's working [Internet]. 2020 [cited: 12 Aug 2020]. Available from: https://www.businessinsider.com/coronavirussouth-korea-tech-contact-tracing-testing-fight-covid19-2020-5

13. Ko J. How China used technology to combat COVID-19 and tighten its grip on citizens [Internet]. 2020 [cited: 10 Sep 2020]. Available from: https://www.amnesty.org/en/latest/news/2020/04 /how-china-used-technology-to-combat-covid-19and-tighten-its-grip-on-citizens/

14. Weinland D. China's Covid-19 QR code surveillance state [Internet]. 2020 [cited: 27 Sep 2020]. Available from: https://www.ft.com/content/eee43c3e-8f7c11ea-9b25-c36e3584cda8

15. Yi Z, Kang S. Fighting COVID-19 with AI: Efforts and lessons from China [Internet]. 2020 [cited: $10 \mathrm{Sep}$ 2020]. Available from: https://www.globaltimes.cn/content/1181846.shtm l

16. Kim MS. South Korea is watching quarantined citizens with a smartphone app [Internet]. 2020 [cited: $10 \mathrm{Sep}$ 2020]. Available from: https://www.technologyreview.com/2020/03/06/9 05459/coronavirus-south-korea-smartphone-appquarantine/

17. Koh D. Singapore government launches new app for contact tracing to combat spread of COVID-19 [Internet]. 2020 [cited: 6 Sep 2020]. Available from: 
https://www.mobihealthnews.com/news/asiapacific/singapore-government-launches-new-appcontact-tracing-combat-spread-covid-19

18. Uibu K. Poland is making its citizens use a 'selfie' app during the coronavirus crisis [Internet]. 2020 [cited: 28 Aug 2020]. Available from: https://www.abc.net.au/news/2020-0425/coronavirus-poland-tracking-quarantine-selfieapp/12173884

19. Worm U, Bruder AE. Germany: COVID-19-App released in Germany [Internet]. 2020 [cited: 5 Oct 2020]. Available from: https://www.mondaq.com/germany/reporting-andcompliance/931666/covid-19-app-released-ingermany

20. Kotz D, Gunter CA, Kumar S, Weiner J. Privacy and security in mobile health: A research agenda. Computer (Long Beach Calif). 2016; 49(6): 22-30. PMID: 28344359 DOI: 10.1109/MC.2016.185 [PubMed]

21. Covid-19 apps pose serious human rights risks [Internet]. 2020 [cited: 29 Aug 2020]. Available from: https://www.hrw.org/news/2020/05/13/covid-19apps-pose-serious-human-rights-risks

22. Van Kolfschooten H, Ruijter A. COVID-19 and privacy in the European Union: A legal perspective on contact tracing. Contemporary Security Policy 2020; 41(3):
478-91.

23. States responses to Covid-19 threat should not halt freedoms of assembly and association-UN expert on the rights to freedoms of peaceful assembly and of association, Mr. Clément Voule [Internet]. 2020 [cited: 17 Sep 2020]. Available from: https://www.ohchr.org/EN/NewsEvents/Pages/Dis playNews.aspx? NewsID $=25788$

24. Everyone included: Social impact of COVID-19 [Internet]. 2020 [cited: 19 Sep 2020]. Available from: https://www.un.org/development/desa/dspd/every one-included-covid-19.html

25. Belzunegui-Eraso A, Erro-Garcés A. Teleworking in the context of the Covid-19 crisis. Sustainability. 2020; 12 : 1-18.

26. Kelley M, Ferrand RA, Muraya K, Chigudu S, Molyneux $\mathrm{S}$, Pai M et al. An appeal for practical social justice in the COVID-19 global response in low-income and middle-income countries. Lancet Global Health. 2020; 8(7): 888-9. PMID: 32416766 DOI: 10.1016/S2214109X(20)30249-7 [PubMed]

27. Elavarasan RM, Pugazhendhi R. Restructured society and environment: A review on potential technological strategies to control the COVID-19 pandemic. Sci Total Environ. 2020; 725: e138858. PMID: 32336562 DOI: 10.1016/j.scitotenv.2020.138858 [․ubMed] 